\title{
Factors related to college students' self-directed learning with technology
}

\author{
Evren Sumuer \\ Kocaeli University, Turkey
}

This study investigated factors influencing college students' self-directed learning with technology. A questionnaire was employed to obtain data from 153 college students on their selfdirected learning readiness, the use of Web 2.0 tools for learning, online communication selfefficacy, and computer self-efficacy to predict their self-directed learning with technology. The data were analysed using sequential multiple regression and mediation analyses. The results showed that the predictor variables explained $19 \%$ of the variation in self-directed learning with technology. Self-directed learning readiness and the use of Web 2.0 tools for learning were found to be significant predictors of students' self-directed learning with technology. Moreover, the results indicate that the use of Web 2.0 tools for learning significantly mediated the influence of students' online communication self-efficacy and computer self-efficacy on their self-directed learning with technology. This study suggests that students be provided with scaffolding or assistance, not only for self-directed learning skills and the use of Web 2.0 tools for learning, but also for computer use and online communication in order to enhance their self-directed learning with technology.

\section{Introduction}

In today's knowledge-based society, lifelong learning is an important prerequisite for coping with economic, occupational and social challenges. It involves 'all general education, vocational education and training, nonformal education and informal learning undertaken throughout life, resulting in an improvement in knowledge, skills and competences within a personal, civic, social and/or employment-related perspective' (European Parliament, \& Council of the European Union, 2006a, p. 50). Individuals need to have several competencies in order to succeed in lifelong learning (European Parliament, \& Council of the European Union, 2006b; Sharma, 2004). These competencies include learners taking more responsibility and initiative to arrange their own learning processes - from the awareness of learning needs to the evaluation of learning results individually or in a group, which refers to self-direction in a learning process. Self-directed learning (SDL) is regarded as both a prerequisite for and the outcome of lifelong learning (Loyens, Magda, \& Rikers, 2008). It enables individuals to take control of their learning by deciding what and how to learn, with or without the support of others (Merriam \& Bierema, 2014).

In higher education, SDL is an important goal for improving the quality of student learning and preparing students for the future (Raidal \& Volet, 2008). It corresponds to the fundamental principles of higher education, including personal autonomy, personal responsibility, and personal growth (Wilcox, 1996). Given the pervasive use of information and communication technologies (ICTs) in higher education, nowadays, SDL with technology warrants further investigation because SDL as a process is particularly enhanced with the affordances of ICTs (Candy, 2004; Lee, Tsai, Chai, \& Koh, 2014; Teo et al., 2010). The use of ICTs influences students' decisions on SDL practices by enabling them to access a wide range of information resources, locate and evaluate information, follow their interests, and interact with experts and peers.

The study investigated factors affecting college students' SDL with technology. It focused particularly on the extent to which SDL readiness, the use of Web 2.0 tools for learning, online communication self-efficacy, and computer self-efficacy are conducive to SDL with technology. This study addressed the following research questions:

(1) How well do SDL readiness, the use of Web 2.0 tools for learning, online communication selfefficacy, and computer self-efficacy predict SDL with technology of college students? 
(2) Does the use of Web 2.0 tools for learning mediate the influence of online communication selfefficacy and computer self-efficacy on SDL with technology?

\section{Background}

\section{SDL}

In an SDL effort, learners take control over the conceptualisation, design, implementation, and evaluation of their learning (Brookfield, 2009). Rather than following initiatives taken by teachers, learners dedicate their efforts to improving their own knowledge, skills, accomplishments, and personal development in their own way and in their own time (Gibbons, 2002). In SDL, teachers can guide students towards finding their own needs and interests and achieving them (Gibbons, 2002). In an SDL process, what needs to be learned, what resources and strategies should be used, and what criteria should be utilised to evaluate learning outcomes are all directed by learners for learning specific skills and knowledge (Brookfield, 2009; Kim, Olfman, Ryan, \& Eryilmaz, 2014). However, this does not mean that SDL refers only to learning in which learners engage individually. It also involves learning in which learners inquire about the learning process through a particular network or learning community including peers, experts, or instructors (Brookfield, 2009; Garrison, 1997; Merriam \& Bierema, 2014).

SDL can be described from three perspectives: a personal attribute, a process, or a design characteristic of the learning environment (Song \& Hill, 2007). Firstly, the degree of self-direction is largely dependent upon learners' personal characteristics required for SDL, including skills and attributes related to motivation, selfmonitoring, self-management, and self-control (Fisher, King, \& Tague, 2001; Garrison, 1997; Guglielmino, 1977; Merriam, 2001; Oddi, 1986). For SDL, learners should possess the necessary personal characteristics at a certain level (Fisher et al., 2001; Guglielmino, 1977), because the degree to which learners have these SDL characteristics influences the extent of their control over their own learning. Secondly, SDL pertains to a process in which learners take control over the instructional steps, including planning, implementing, and evaluating learning (Merriam \& Bierema, 2014; Song \& Hill, 2007). Knowles (1975) defines SDL as a process consisting of five steps: (a) diagnosing learning goals; (b) formulating learning goals; (c) identifying human and material resources for learning; (d) choosing and implementing appropriate learning strategies; and (e) evaluating learning outcomes. Lastly, SDL is considered as a design characteristic of a learning environment which fosters the control of learners over learning (Loyens et al., 2008). A learning context can be designed to incorporate elements that influence to what extent learners control and direct their own learning process. For example, online learning environments can provide learners with a learning context involving resources, structure, tasks, feedback from instructors, and peer collaboration to facilitate or enhance SDL (Song \& Hill, 2007). In conclusion, SDL is likely to occur in a learning context that supports learners in planning, implementing, and evaluating learning with the use of skills and attributes such as motivation, selfmanagement, and self-control.

The affordances of ICTs can provide learners with opportunities to enhance the SDL process. For example, the capacity to access abundant and diverse information resources; capture, store, manipulate, and display information; and have contact with online experts and peers can allow learners to use ICTs to identify their learning needs, choose and implement appropriate learning content, resources and strategies, and evaluate their learning outcomes, which stimulate self-direction in their learning process (Candy, 2004; Lee et al., 2014; Teo et al., 2010).

\section{SDL with technology}

SDL with technology refers to the use of ICTs for learning experiences that enable individuals to take control of planning, implementing, and evaluating their own learning (Lee et al., 2014; Teo et al., 2010). Examples of how ICTs can influence the SDL process include collaboration with people, convenient and persistent access to worldwide information resources and opportunities, online communities involving a number of people from various disciplines for collaborative working and learning, and creative abilities cultivated through 
digital technologies (Karakas \& Manisaligil, 2012). Furthermore, learners can diagnose and formulate their learning needs, identify learning paths, or evaluate their learning outcomes with the help of these ICTs. Rashid and Asghar (2016) found that learners' use of technologies such as email, smartphone, Internet, and social media positively influenced their levels of SDL. Moreover, Gabrielle (2003) found that technologymediated instructional strategies designed using Keller's (1987) attention, relevance, confidence, satisfaction (ARCS) model of motivation and delivered via several technologies such as personal digital assistants, the Web, videos, and email had positive impacts on SDL. Consequently, technology-rich environments have the potential to provide flexible opportunities and capabilities for learners to facilitate SDL.

Online learning environments, especially, can provide a conducive context for SDL personal characteristics and process. The flexible structure of these learning environments enables learners to accommodate their own needs in their own time, place, and pace and consequently makes it possible for them to have more control over their own learning (Beach, 2017; Vonderwell \& Turner, 2005). As a result, a well-designed online learning environment that provides a flexible structure, collaboration opportunities, and choice and control over learning can provide learners with the opportunity to pursue SDL process effectively.

In order to take advantage of ICTs for SDL, it is important to understand the factors that foster and facilitate SDL with technology. Such evidence would make it possible for learners, instructors, or instructional designers to employ appropriate scaffolding strategies for effective SDL with technology. Similarly, in a study in which a self-report instrument was developed to measure SDL with technology among young students (aged 10-12), Teo et al. (2010) placed emphasis on the need for further studies that examine factors influencing SDL with technology. For these, they suggested the investigation of constructs that affect SDL and user demographics. Although studies have mostly focused on the influence of technology use on SDL, there is scant research to be found on the factors influencing SDL with technology. Therefore, this current study investigated the influence of factors that affect SDL (i.e., SDL readiness and the use of Web 2.0 tools for learning) and the characteristics of college students (i.e., online communication self-efficacy and computer self-efficacy) on SDL with technology.

\section{SDL readiness}

In order to benefit from the affordances of the learning context for SDL, learners should be ready for selfdirection. SDL readiness is defined as the extent to which learners have the attitude, abilities, and personality traits required for SDL (Wiley, 1983). According to Fisher et al. (2001), this definition inherently assumes that readiness for SDL changes along a continuum and that learners are placed somewhere on it. Consistent with this perspective, Lai (2011) explored learners' SDL readiness as having an important influence on their online learning effectiveness in a Web-based learning environment. Similarly, a study conducted by Lee et al. (2014) found that learners who reported engaging in SDL were more likely to effectively harness the affordances of ICTs for SDL. In addition, Chu and Tsai (2009) showed that the more learners are ready for SDL, the more likely they are to prefer constructivist Internet-based learning environments, which is conducive for SDL. These findings suggest that learners' SDL readiness is an important antecedent of SDL with technology. If learners have the attitude, abilities, and personality traits required for SDL, they are more likely to take advantage of the affordances of ICTs for SDL. Therefore, it is important to examine the extent to which learners' SDL readiness contributes to SDL with technology.

One of the most widely used instruments measuring SDL readiness is Guglielmino's (1977) Self-Directed Learning Readiness Scale. It measures eight constructs representing necessary attributes and skills for learners to engage in SDL. Due to inherent problems of the SDLRS related to construct validity and reliability (Bonham, 1991; Field, 1989; Hoban, Lawson, Mazmanian, Best, \& Seibel, 2005), Fisher et al. (2001) developed a valid and reliable scale to measure readiness for SDL. It focuses on three attributes of selfdirected learners, namely self-management, desire for learning, and self-control. In light of this framework, the current study suggests that college students with a strong desire to learn and the ability to manage and control their own learning are more likely to benefit from technology for SDL. 


\section{Use of Web 2.0 tools for learning}

Given the prevalent use of the Internet and mobile devices, Web 2.0 technologies are one of the most important ICTs that support SDL activities due to their capabilities for informal conversation, dialogue, collaborative content creation, and knowledge sharing, which help learners be more autonomous in their own learning (McLoughlin \& Lee, 2010). Firstly, by using these technologies, learners can explore, express, and share their thoughts, understanding, and experiences independently and publicly (Kitsantas \& Dabbagh, 2011; Lin, 2008; Robertson, 2011). These features enable learners to express their understanding of content and self-reflect on their learning experiences. Secondly, Web 2.0 tools or applications enable learners to challenge, contribute, and co-create knowledge, questions for exploration, and ideas collaboratively with not only other learners or instructors, but also with others around the globe who have similar interests (Karakas \& Manisaligil, 2012; Lin, 2008). Moreover, the collaborative nature of Web 2.0 makes it possible for learners to receive help, support, and feedback from peers and experts in order to guide their learning experiences (Karakas \& Manisaligil, 2012; McLoughlin \& Lee, 2010). Web 2.0-mediated social interaction with peers, instructors, or experts also enables learners to critically test and confirm their understanding (Lin, 2008). These collaborative efforts can help learners not only to fulfill their learning goals through collaboration and social interaction, but also to make informed decisions on, or revise, their learning goals, learning resources, strategies, and evaluation of their learning results. Lastly, Web 2.0 technologies provide a range of tools and services which learners can use based on their needs and preferences (Karakas \& Manisaligil, 2012). These tools and services provide learners with a context or resources for learning. Consequently, the opportunities and abilities of Web 2.0 tools have a significant potential to facilitate and foster SDL.

Several studies have demonstrated the capacity of various Web 2.0 tools for SDL. Callaghan and Bower (2012) found that the use of a social network site within a high school led learners to self-directed learning by enabling them to complete tasks autonomously with the opportunity to study collaboratively. Moreover, in a study on the use of online social networking educational activities in higher education, Hamid, Waycott, Kurnia, and Chang (2015) found that students using social technologies were able discover new knowledge independently and collaboratively, which is an indication of SDL. In addition, based on the qualitative analysis of blog entries as a form of design diary for a creative design project, Robertson (2011) showed that college students made use of the educational affordances of blogs to take initiative and responsibility for their own learning efforts within a socially and cognitively supportive environment. Furthermore, Park (2013) investigated the effect of a social network game on SDL using an experimental design, and revealed that college students who utilised a social network game with a high interaction structure improved SDL. The study conducted by Kim et al. (2014) also found that a wiki platform supported SDL by enabling students to set specific learning goals, reflect on their learning experiences, monitor their activities, and collaborate with other students. Consequently, it is clear that the use of Web 2.0 tools for learning inherently offers considerable potential for SDL. Hence, this study suggests that the use of Web 2.0 tools for learning purposes is likely to contribute to SDL with technology.

\section{Online communication self-efficacy}

As stated, SDL does not only refer to learning undertaken in isolation from others. It also includes peer networking, collaboration, and social interaction with other learners, all of which facilitate the SDL process (Brookfield, 2009; Candy, 2004; Robertson, 2011). The opportunity for learners to interact with others plays a critical role in building knowledge, finding resources, and controlling and evaluating learning experiences. Especially, computer-based learning environments offer learners tools which foster interaction and collaboration with others (Ryan, 2012). Since communication is a necessary and important part of an interactive learning environment (de Bruyn, 2004), learners' beliefs about their capabilities to communicate with others in online environments are likely to impact on the success of SDL with technology. To benefit from social networking, collaboration, and social interaction for SDL, learners need to communicate in a comfortable and confident way through asynchronous and synchronous tools. Online communication selfefficacy is also determined as one of the underlying dimensions of students' readiness for online learning (Hung, Chou, Chen, \& Own, 2010), which presents a conducive context for SDL. Thus, this study considers online communication self-efficacy as another factor likely to impact SDL with technology. 
Furthermore, online communication self-efficacy can influence SDL with technology through its influence on the use of Web 2.0 tools for learning. Web 2.0 tools make it possible for learners to communicate and collaborate with each other (Ryan, 2012). Communication and collaboration with others enable learners to take advantage of the affordance of Web 2.0 tools regarding peer networks, collaboration, and social learning (Kim et al., 2014). Learners with high online communication self-efficacy are likely to benefit more from Web 2.0 tools for learning. Therefore, given the capabilities of Web 2.0 tools for SDL, this study suggests that online communication self-efficacy contributes to SDL with technology through its influence on the use of Web 2.0 tools for learning.

\section{Computer self-efficacy}

Computer self-efficacy has an impact on the extent to which learners use computer-related technologies effectively, thereby influencing how successful they use ICTs to pursue SDL activities. Self-efficacy refers to a person's judgement about his/her own capability to perform a certain task (Bandura, 1986). Computer selfefficacy is a more specific variable which represents people's beliefs about their abilities to use a computer (Compeau \& Higgins, 1995). In general, it plays an important role in learning and the learning process in computer-based learning environments (Moos \& Azevedo, 2009). A study undertaken by Simmering, Posey, and Piccoli (2009) found computer self-efficacy to be positively related to learning in a self-directed online course. Similarly, Teo, Wan, Chan, and Lim (2002) showed the influence of computer self-efficacy on SDL in an ICT-based learning environment. In addition, a study conducted by Holt and Brockett (2012) showed a significant, but weak, correlation between self-direction and computer self-efficacy among graduating seniors. Consequently, this study argues that learners are more likely to feel comfortable in performing tasks with ICTs for SDL if they have a high level of computer efficacy.

In addition to the direct impact of computer self-efficacy on SDL with technology, it can influence SDL with technology through its effect on the use of Web 2.0 tools for learning. Previous studies provided ample evidence that computer self-efficacy has an impact on the degree to which learners engage in Web 2.0 tools (Sadaf, Newby, \& Ertmer, 2012; Söylemez \& Oral, 2013; Wang, Xu, \& Chan, 2014). Thus, computer selfefficacy influences the extent to which learners harness the affordances of Web 2.0 tools for learning. As a result, it is viable to conclude that computer self-efficacy has an impact on the use of Web 2.0 tools for learning, which in turn influences SDL with technology.

\section{Methodology}

This study is based on a correlational research design, as it is a prediction study that focused on the predictors of SDL with technology. It draws on SDL readiness, the use of Web 2.0 tools for learning, online communication self-efficacy, and computer self-efficacy to predict SDL with technology.

\section{Participants}

The participants of the study consisted of 153 undergraduate students in the School of Education at a public university in Turkey. Most of the participants (79.1\%) were female. The age of the participants ranged from 20 to 27 years, with a mean of 22.06 years $(S D=1.24)$. Of the participants, $44.4 \%$ reported having a good knowledge level of using computers, whereas $38.6 \%$ reported a moderate level. Almost half $(49.7 \%)$ of the participants indicated having moderate computer experience. Slightly more than half (52.3\%) reported using computers often. The majority (90.2\%) of the participants had their own computer, while almost all (98.0\%) had access to the Internet. Three-quarters (75.2\%) of the participants stated that they were comfortable when using computers.

\section{Instrumentation}

In this study, data were collected through a questionnaire that consisted of scales developed in previous studies. These are explained below. 
SDL with technology was measured by the Self-Directed Learning with Technology Scale for Young Students (Teo et al., 2010), which was adapted into Turkish by Demir and Yurdugül (2013). It is a six-item, two-factor self-report instrument using a 5-point Likert scale (ranging from 1 for strongly disagree to 5 for strongly agree), measuring self-management (two items) and intentional learning (four items). The content validity of the items for college students was assured by an expert in the field of instructional technology. The Cronbach coefficient alpha values of the Turkish version of the scale were found to be 73 (Demir \& Yurdugül, 2013). In the current study, the Cronbach alpha reliability for the scale was .67, which shows moderate reliability.

The use of Web 2.0 tools for learning was measured by a scale adapted from Sadaf et al. (2012). The scale contains seven items with a 5-point Likert scale (ranging from 1 for never to 5 for always), each of which measures to what extent students use a specific Web 2.0 tool such as blogs, wikis, social networks, social bookmarks, instant messaging, video chat, and video editing/sharing for learning purposes. In the current study, the Cronbach alpha reliability for the scale was .76, indicating sufficiently high reliability.

SDL readiness was measured by the Self-Directed Learning Readiness Scale (Fisher et al., 2001), which was adapted into Turkish by Şahin and Erden (2009). It consists of 40 items using a 5-point Likert scale (ranging from 1 strongly disagree to 5 strongly agree), which measures three factors: self-management (13 items), desire for learning (12 items), and self-control (15 items). The Cronbach alpha reliability coefficients of the Turkish version were found to be .87 for self-management (13 items), .86 for desire for learning (16 items), and .79 for self-control (11 items) (Şahin \& Erden, 2009). In the current study, the Cronbach alpha reliability for the scale was .94, which suggests high reliability. Some examples of the items are 'I am systematic in my learning', 'I enjoy learning new information', and 'I can find out information for myself'.

Online communication self-efficacy was measured by a sub-scale of the Online Learning Readiness Scale (Hung et al., 2010), which measures the degree to which learners are comfortable and confident in online communication. It was adapted into Turkish by Yurdugül and Sirakaya (2013), and includes three items using a 5-point Likert scale (ranging from 1 strongly disagree to 5 strongly agree). The Cronbach alpha reliability coefficient of the Turkish version of the sub-scale was found to be .91 (Yurdugül \& Sirakaya, 2013). In the current study, the Cronbach alpha reliability for the scale was .85, which indicates high reliability. An example item from the scale is 'I feel confident in posting questions in online discussions'.

The Computer Self-Efficacy Belief Scale, developed in Turkish by Aşkar and Umay (2001), was used to measure students' computer self-efficacy. It includes 18 items on a 5-point Likert scale (ranging from 1 for never to 5 for always). The Cronbach alpha value of the scale was .71 (Asskar \& Umay, 2001). In the current study, the Cronbach alpha reliability for the scale was .72, which shows sufficiently high reliability. Some examples of the items are 'I use a computer to schedule my day/time', 'I think I use computers effectively', and 'When using a computer, I am nervous'.

The questionnaire also included questions related to the participants' demographics. In addition, it contained single-item questions measuring students' computer knowledge level, computer experience, computer use, and their comfort level in using a computer.

\section{Data collection and analysis}

The researcher administered the questionnaire to pre-service teachers who voluntarily participated during their class time. They were assured that their responses would remain confidential and anonymous. The institutional ethics committee granted permission for this study.

A sequential regression analysis (Tabachnick \& Fidell, 2007) was performed to identify how well SDL with technology is predicted from SDL readiness, use of Web 2.0 tools for learning, online communication selfefficacy, and computer self-efficacy, and the relative contribution of these variables to the prediction. In the analysis, the predictor variables were entered sequentially based on their importance determined by the researcher. In order to predict SDL with technology, the first predictor variable entered into the regression 
model was SDL readiness, followed by use of Web 2.0 tools for learning, online communication self-efficacy, and computer self-efficacy. Given the fact that a sample size of 84 is deemed sufficient to achieve a statistical power of $80 \%$ for detecting a multiple correlation coefficient value of at least 0.25 with a $5 \%$ probability of error (Cohen, 1992), the sample size of the study was considered sufficiently adequate to obtain data for the model in order to accurately predict the outcome variable. In order to proceed with the parametric regression analysis, preliminary analyses were conducted to ensure there were no violation of assumptions of multicollinearity, homoscedasticity, independent errors, normality, and linearity.

In order to investigate how the use of Web 2.0 tools for learning mediates the influence of online communication self-efficacy and computer self-efficacy on SDL with technology, this study employed a mediation analysis following the principles suggested by Hayes (2013). This analysis examined the indirect effect of online communication self-efficacy and computer self-efficacy on SDL with technology through the use of Web 2.0 tools for learning. The analysis of the indirect effect accounts for how SDL with technology is influenced by online communication self-efficacy and computer self-efficacy through their influence on the use of Web 2.0 tools for learning, which in turn influences SDL with technology. Due to having no assumption about the normality of the sampling distribution of the indirect effect and higher power (Hayes, 2013), the bias-corrected bootstrap confidence interval method was chosen for inference about the indirect effects in this study. In this method, bias-corrected bootstrap confidence intervals were calculated by repeatedly random resampling from the original sample with replacement and then estimating the indirect effect in each sample. If the upper and lower bounds of a $95 \%$ bias-corrected bootstrap confidence interval do not contain zero, it can be claimed with $95 \%$ confidence that the indirect effect is statistically significant. The mediation analyses were performed using the PROCESS add-on for SPSS (http://www.processmacro.org), which was developed for mediation, moderation, and conditional process analysis (Hayes, 2013).

\section{Results}

A sequential multiple regression analysis was conducted in order to determine to what extent SDL with technology is predicted from SDL readiness, the use of Web 2.0 tools for learning, online communication self-efficacy, and computer self-efficacy. The correlations among the variables showed there to be a medium, positive significant correlation between SDL with technology and SDL readiness $(r=.37, p<.001)$. In addition, there was a small, positive significant correlation of SDL with technology with the use of Web 2.0 tools for learning $(r=.29, p<.001)$, online communication self-efficacy $(r=.26, p<.01)$, and computer selfefficacy $(r=.22, p<.01)$. Table 1 summarises the correlations among predictor variables and outcome variable.

Table 1

Means, standard deviations, and inter-correlations among predictor variables and outcome variable

\begin{tabular}{lcccccc}
\hline \multicolumn{1}{c}{ Variable } & $\boldsymbol{M}$ & SD & $\mathbf{1}$ & $\mathbf{2}$ & $\mathbf{3}$ & $\mathbf{4}$ \\
\hline SDLT & 3.92 & 0.54 & $.37^{* *}$ & $.29^{* *}$ & $.26^{* *}$ & $.22 * *$ \\
Predictor variable & & & & & & \\
$\quad$ 1. SDLR & 3.97 & 0.45 & -- & & & \\
2. UWTL & 3.26 & 0.71 & $.19^{* *}$ & -- & & \\
$\quad$ 3. OCSE & 3.88 & 0.76 & $.34^{* *}$ & $.36^{* *}$ & -- & \\
$\quad$ 4. CSE & 3.33 & 0.61 & $.36^{* *}$ & $.43^{* *}$ & $.41^{* *}$ & -- \\
\hline
\end{tabular}

Note. $*<.05 ; * *<.01$.

SDLT: Self-directed learning with technology; SDLR: Self-directed learning readiness; UWTL: Use of Web 2.0 tools for learning; OCSE: Online communication self-efficacy; CSE: Computer self-efficacy.

In the regression analysis, the predictor variables were entered into the model sequentially. First, the model with only SDL readiness (Step 1) accounted for $14 \%$ of variance in SDL with technology, $F(1,151)=23.99$, $p<.01$. Second, when use of Web 2.0 tools for technology was added (Step 2), the model accounted for 19\% variance in SDL with technology, $F(2,150)=17.08, p<.01$. An additional $5 \%$ of variation explained in SDL with technology is attributed to use of Web 2.0 tools for learning, $F_{\text {inc }}(1,150)=8.91, p<.01$. Third, the 
model into which online communication self-efficacy was entered (Step 3) did not change the variance explained by the model, $F(3,149)=11.75, p<.01$. It remained as $19 \%$. Last, when computer self-efficacy was entered into the model, it still explained $19 \%$ of variation in SDL with technology, $F(4,148)=8.76, p<$ .01. There was no significant change in the variance accounted for by the addition of either online communication self-efficacy, $F_{\text {inc }}(1,149)=1.07, p=.30$, or computer self-efficacy, $F_{\text {inc }}(1,148)=.02, p=$ .90 , into the regression model. Table 2 summarises the results of the regression analysis.

Table 2

Results of sequential regression analysis

\begin{tabular}{|c|c|c|c|c|c|}
\hline Variable & B & SEB & $\beta$ & $\mathbf{R}^{2}$ & $\Delta \mathrm{R}^{2}$ \\
\hline Step1 & & & & $.14^{* *}$ & $.14^{* *}$ \\
\hline SDLR & .45 & .09 & $.37 * *$ & & \\
\hline Step 2 & & & & $.19 * *$ & $.05^{* *}$ \\
\hline SDLR & .39 & .09 & $.33 * *$ & & \\
\hline UWTL & .17 & .06 & $.22 * *$ & & \\
\hline Step 3 & & & & $.19^{* *}$ & .01 \\
\hline SDLR & .36 & .09 & $.30^{* *}$ & & \\
\hline UWTL & .15 & .06 & $.20^{*}$ & & \\
\hline OCSE & .06 & .06 & .09 & & \\
\hline Step 4 & & & & $.19 * *$ & .00 \\
\hline SDLR & .37 & .10 & $.31^{* *}$ & & \\
\hline UWTL & .15 & .06 & $.20 *$ & & \\
\hline OCSE & .06 & .06 & .09 & & \\
\hline CSE & -.01 & .08 & -.01 & & \\
\hline
\end{tabular}

Note. $*<.05 ; * *<.01$.

SDLT: Self-directed learning with technology; SDLR: Self-directed learning readiness; UWTL: Use of Web 2.0 tools for learning; OCSE: Online communication self-efficacy; CSE: Computer self-efficacy.

These findings reveal that $19 \%$ of the variation in SDL with technology was predicted from SDL readiness, the use of Web 2.0 tools for learning, online communication self-efficacy, and computer self-efficacy. In other words, they show that SDL with technology was moderately predicted with these predictor variables. However, SDL readiness $(\beta=.31, p<.01)$ and use of Web 2.0 tools for learning $(\beta=.20, p<.05)$ were found to be significant predictors of SDL with technology. The most important predictor of SDL with technology was SDL readiness, which explains $14 \%$ of the variation in SDL with technology. Neither online communication self-efficacy ( $\beta=.09, p=.30)$ nor computer self-efficacy $(\beta=-.01, p=.90)$ made any direct contribution to the prediction of SDL with technology. However, significant bivariate correlation of online communication self-efficacy and computer self-efficacy with SDL with technology suggested that the indirect effect of online communication self-efficacy and computer self-efficacy on SDL with technology was a plausible explanation for this observed relationship.

A mediation analysis was used to investigate the indirect contribution of online communication self-efficacy to predicting SDL with technology through the use of Web 2.0 tools for learning after controlling the effect of the other variables (i.e., computer self-efficacy and SDL readiness). The upper and lower bounds of a 95\% bias-corrected bootstrap confidence interval for the indirect contribution of online communication selfefficacy using 10,000 bootstrap samples were found to be .002 and .099, respectively. The $95 \%$ bias-corrected bootstrap confidence interval was above zero, and therefore it was concluded that there was a significant indirect contribution of online communication self-efficacy to SDL with technology through the use of Web 2.0 tools for learning. Regression coefficients, standard errors, and model summary information are presented in Table 3. 
Table 3

Regression coefficients, standard errors, and model summary information for the contribution of online communication self-efficacy to predicting SDL with technology after controlling the effect of computer selfefficacy and SDL readiness

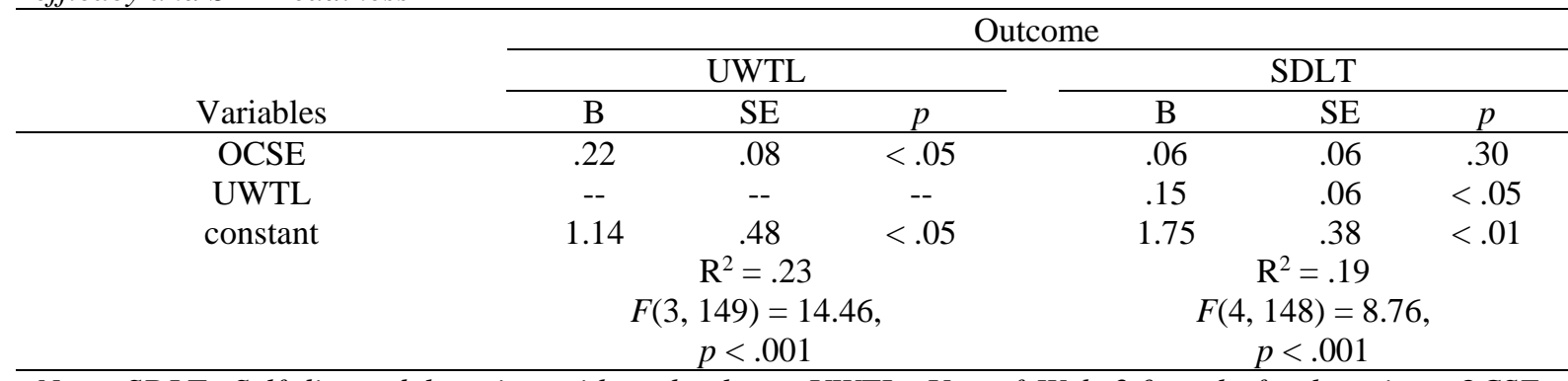

Note. SDLT: Self-directed learning with technology; UWTL: Use of Web 2.0 tools for learning; OCSE: Online communication self-efficacy.

Another mediation analysis was also conducted to investigate the indirect effect of computer self-efficacy on SDL with technology through the use of Web 2.0 tools for learning after controlling the effect of the other variables (i.e., online communication self-efficacy and SDL readiness). The upper and lower bounds of a 95\% bias-corrected bootstrap confidence interval using 10,000 bootstrap samples were found to be .013 and .121, respectively. The 95\% bias-corrected bootstrap confidence interval was above zero, and therefore it was concluded that there was a significant indirect contribution of computer self-efficacy to SDL with technology through the use of Web 2.0 tools for learning. Regression coefficients, standard errors, and model summary information are given in Table 4. Figure 1 summarises the direct influences of SDL readiness and the use of Web 2.0 tools for learning and the indirect influences of online communication self-efficacy and computer self-efficacy on SDL with technology.

Table 4

Regression coefficients, standard errors, and model summary information for the contribution of computer self-efficacy to predicting SDL with technology after controlling the effect of online communication selfefficacy and SDL readiness

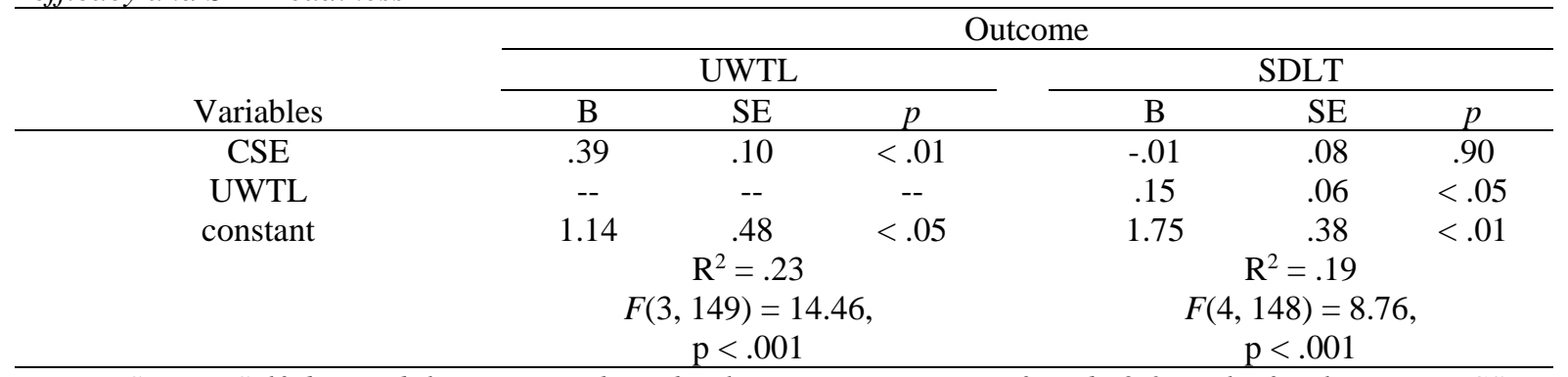

Note. SDLT: Self-directed learning with technology; UWTL: Use of Web 2.0 tools for learning; CSE: Computer self-efficacy. 


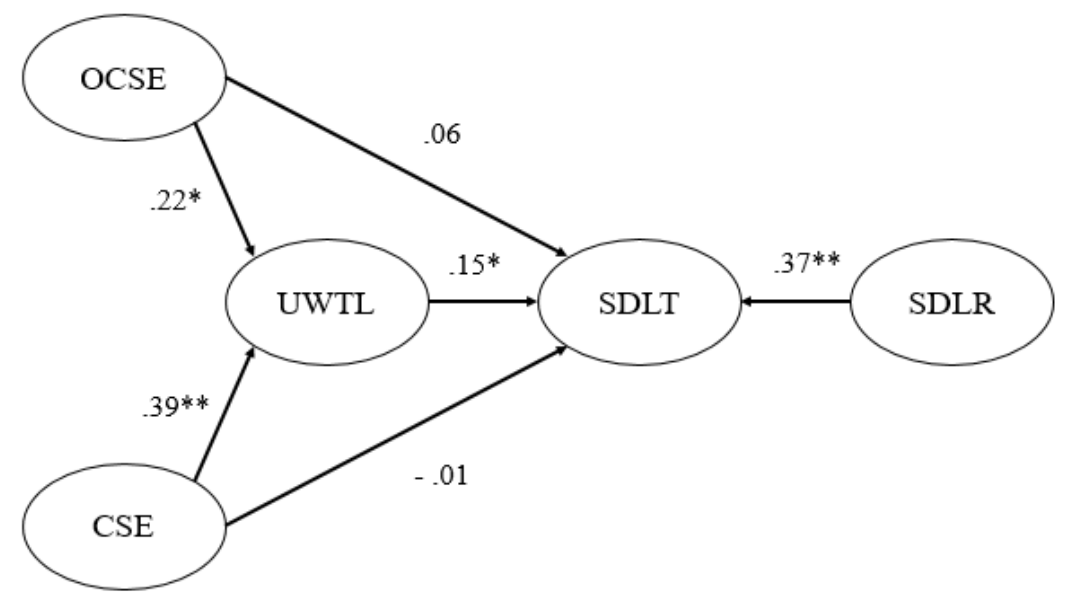

Figure 1. Results of the study Note. $*<.05 ; * *<.01 . \mathrm{R}^{2}=.19$.

SDLT: Self-directed learning with technology; SDLR: Self-directed learning readiness; UWTL: Use of Web 2.0 tools for learning; OCSE: Online communication self-efficacy; CSE: Computer self-efficacy.

\section{Discussion}

This study was conducted to investigate the extent to which SDL readiness, the use of Web 2.0 tools for learning, online communication self-efficacy, and computer self-efficacy are conducive to college students' SDL with technology. The results of the study indicate that the combined effect of these variables had moderate predictive ability for SDL with technology, explaining 19\% of variance in college students' SDL with technology. However, according to regression coefficients and their significance, this study found that SDL readiness and the use of Web 2.0 tools for learning had a statistically significant direct contribution to SDL with technology. This means that the more learners are ready for SDL and use Web 2.0 tools for learning, the more effectively they can experience SDL with technology. In addition, the results reveal that the students' SDL readiness was found to be a more important predictor of SDL with technology than the use of Web 2.0 tools for learning. This finding clearly suggests that learners' readiness for SDL is relatively more influential on their use of ICT for SDL. The extent to which the learners have the attitude, abilities and personality traits needed for SDL is likely to influence the extent to which they benefit from ICTs for SDL. This finding is consistent with previous studies (Chu \& Tsai, 2009; Lee et al., 2014), which place emphasis on the important role of SDL readiness on the use of ICTs for SDL. Therefore, in order to encourage the use of technology for SDL, it is possible to stimulate college students' level of self-direction by teaching them SDL skills and providing them with guidance or counselling in SDL activities.

Based on regression coefficients and their significance, this study also shows that college students' Web 2.0 tool usage for learning makes a statistically significant unique direct contribution to the prediction of their SDL with technology. This finding suggests that students' use of Web 2.0 tools for learning accounts for their use of ICTs for SDL. It is supported by prior studies (Callaghan \& Bower, 2012; Hamid et al., 2015; Kim et al., 2014; Park, 2013; Robertson, 2011), which indicate how SDL practices are facilitated by Web 2.0 tools such as social networking sites, blogs, wikis, and social network games. The capabilities of Web 2.0 tools for engagement, interaction, participation, collaboration, and sharing provide learners with the context and resources to perform SDL practices (Karakas \& Manisaligil, 2012). Therefore, this study confirms that the use of Web 2.0 for learning is likely to play an important role on the use of ICTs for SDL. However, in learning environments, scaffolding or assistance should be provided for students to take the advantage of Web 2.0 for learning in order to foster and facilitate their ICT usage for SDL.

The results of this study also reveal that online communication self-efficacy and computer self-efficacy make a statistically significant indirect contribution to SDL with technology through the use of Web 2.0 tools for 
learning, although they did not make a statistically significant direct contribution. This finding confirms that the use of Web 2.0 tools for learning mediates the influence of college students' online communication selfefficacy and computer self-efficacy on their SDL with technology. Since learning through the use of Web 2.0 tools is mainly based on peer networks, collaboration, and social learning (Kim et al., 2014), communication and collaboration with others play an especially vital role in using the capabilities of these environments for learning. Thus, online communication self-efficacy is considered an essential characteristic for college students to be successful in such online learning environments (Hung et al., 2010). In addition, as highlighted in previous studies, computer self-efficacy plays a determinant role in the use of Web 2.0 capabilities for learning (Sadaf et al., 2012; Söylemez \& Oral, 2013; Wang et al., 2014). Through the influence of online communication self-efficacy and computer self-efficacy on the use of Web 2.0 tools for learning, this study suggests that they are likely to contribute to SDL with technology. This means that the extent to which college students' beliefs about their abilities to communicate online and use computers could influence their use of Web 2.0 tools for learning, which in turn is likely to affect SDL with technology. These variables could exert their influences on SDL with technology through services, tools, and applications used for SDL practices. Therefore, for better SDL with technology, students, especially those with low online communication selfefficacy and computer self-efficacy, should be encouraged to use computers and communicate with others more effectively by providing scaffolding and assistance during their use of services, tools, and applications for SDL.

Despite the fact that this study reveals important findings on the predictors of SDL with technology, these findings should be interpreted in light of the following limitations. Firstly, this study is limited by its participants' over-represented of female students in the School of Education at a university in Turkey. Although the information on demographics and other characteristics of the participants helps others to judge the degree to which they represent the population, there is a need for more research that investigates SDL with technology with different samples of higher education. Secondly, in this study, the Cronbach alpha's value of the scale measuring SDL with technology was found to be just below the acceptable limit. Thirdly, the large amount of variation in SDL with technology was not explained in the study. Further studies could be conducted in order to explore the predictive ability of the variables considered to affect SDL with technology, such as collaborative learning and the demographics of students (Lee et al., 2014; Teo et al., 2010). Despite the need for further studies, the results of the study may be taken into consideration for practice, especially in designing technology-enhanced learning environments for SDL.

\section{Conclusion}

This study shows that SDL readiness, the use of Web 2.0 tools for learning, online communication selfefficacy, and computer self-efficacy are factors that account for the limited proportion of college students' SDL with technology. SDL readiness and the use of Web 2.0 tools for learning were found to be significant factors that make a direct contribution to college students' SDL with technology. Despite their non-significant direct influence on SDL with technology, online communication self-efficacy and computer self-efficacy have a significant indirect influence through the mediating effect of Web 2.0 tools usage for learning. Based on the findings, college students, instructors, or instructional designers could select and use resources and strategies that make SDL with technology experiences more effective and efficient. Moreover, technology-enhanced learning environments could be designed to provide college students with improved opportunities for SDL. Therefore, this study argues that scaffolding or assistance should be offered to college students in order to support their abilities for SDL, the use of Web 2.0 tools for learning, online communication, and computers, whereby they could benefit from ICT for SDL. Nevertheless, there is a need for further studies to investigate factors that influence college students' SDL with technology. 


\section{References}

Aşkar, P., \& Umay, A. (2001). İlköğretim matematik öğretmenliği öğrencilerinin bilgisayarla ilgili öz-yeterlik algis1 [Perceived computer self-efficacy of the students in the elementary mathematics teaching programme]. Hacettepe Üniversitesi Eğitim Fakültesi Dergisi, 21, 1-8. Retrieved from http://dergipark.ulakbim.gov.tr/hunefd/article/download/5000048902/5000046222

Bandura, A. (1986). Social foundations of thought and task: A social cognitive theory. Englewood Cliffs, NJ: Prentice-Hall.

Beach, P. (2017). Self-directed online learning: A theoretical model for understanding elementary teachers' online learning experiences. Teaching and Teacher Education, 61, 60-72. https://doi.org/10.1016/j.tate.2016.10.007

Bonham, L. A. (1991). Guglielmino’s self-directed learning readiness scale: What does it measure? Adult Education Quarterly, 41(2), 92-99. https://doi.org/10.1177/0001848191041002003

Brookfield, S. D. (2009). Self-directed learning. In R. Maclean \& D. Wilson (Eds.), International handbook of education for the changing world of work: Bridging academic and vocational learning (pp. 26152627). Dordrecht: Springer. https://doi.org/10.1007/978-1-4020-5281-1_172

Callaghan, N., \& Bower, M. (2012). Learning through social networking sites - the critical role of the teacher. Educational Media International, 49(1), 1-17. https://doi.org/10.1080/09523987.2012.662621

Candy, P. C. (2004). Linking thinking: Self-directed learning in the digital age. Canberra: Department of Education, Science and Training. Retrieved from http://vital.new.voced.edu.au/vital/access/services/Download/ngv:31516/SOURCE2

Chu, R. J. C., \& Tsai, C. C. (2009). Self-directed learning readiness, Internet self-efficacy and preferences towards constructivist Internet-based learning environments among higher-aged adults. Journal of Computer Assisted Learning, 25(5), 489-501. https://doi.org/10.1111/j.1365-2729.2009.00324.x

Cohen, J. (1992). A power primer. Psychological Bulletin, 112(1), 155-159. https://doi.org/10.1037/00332909.112.1.155

Compeau, D. R., \& Higgins, C. A. (1995). Computer self-efficacy: Development of a measure and initial test. MIS Quarterly, 19(2), 189-211. https://doi.org/10.2307/249688

de Bruyn, L. L. (2004). Monitoring online communication: Can the development of convergence and social presence indicate an interactive learning environment? Distance Education, 25(1), 67-81. https://doi.org/10.1080/0158791042000212468

Demir, Ö., \& Yurdugül, H. (2013). Self-directed learning with technology scale for young students: A validation study. e-international Journal of Educational Research, 4(3), 58-73. Retrieved from http://dergipark.ulakbim.gov.tr/ijer/article/download/1073000316/1073000133

European Parliament, \& Council of the European Union. (2006a). Decision No 1720/2006/EC of the European Parliament and of the Council of 15 November 2006: Establishing an action programme in the field of lifelong learning. Official Journal of the European Union, L 327, 45-68. Retrieved from http://eur-lex.europa.eu/legal-content/EN/TXT/PDF/?uri=CELEX:32006D1720\&from=EN

European Parliament, \& Council of the European Union. (2006b). Recommendation of the European Parliament and of the Council of 18 December 2006 on key competences for lifelong learning. Official Journal of the European Union, L 394, 10-18. Retrieved from http://eur-lex.europa.eu/legalcontent/EN/TXT/PDF/?uri=CELEX:32006H0962\&from=EN

Field, L. (1989). An Investigation into the structure, validity, and reliability of Guglielmino's self-directed learning readiness scale. Adult Education Quarterly, 39(3), 125-139. https://doi.org/10.1177/0001848189039003001

Fisher, M., King, J., \& Tague, G. (2001). Development of a self-directed learning readiness scale for nursing education. Nurse Education Today, 21(7), 516-525. https://doi.org/10.1054/nedt.2001.0589

Gabrielle, D. M. (2003). The effects of technology-mediated instructional strategies on motivation, performance, and self-directed learning (Doctoral dissertation). Retrieved from ProQuest database. (Accession no. 305327247)

Garrison, D. R. (1997). Self-directed learning: Toward a comprehensive model. Adult Education Quarterly, 48(1), 18-33. https://doi.org/10.1177/074171369704800103 
Gibbons, M. (2002). The self-directed learning handbook: Challenging adolescent students to excel. San Francisco, CA: Jossey-Bass.

Guglielmino, L. M. (1977). Development of the self-directed learning readiness scale (Doctoral dissertation). Retrieved from ProQuest database. (Accession no. 302856217)

Hamid, S., Waycott, J., Kurnia, S., \& Chang, S. (2015). Understanding students' perceptions of the benefits of online social networking use for teaching and learning. The Internet and Higher Education, 26, 1-9. https://doi.org/10.1016/j.iheduc.2015.02.004

Hayes, A. F. (2013). Introduction to mediation, moderation, and conditional process analysis: A regressionbased approach. New York, NY: The Guilford Press.

Hoban, J. D., Lawson, S. R., Mazmanian, P. E., Best, A. M., \& Seibel, H. R. (2005). The self-directed learning readiness scale: A factor analysis study. Medical Education, 39(4), 370-379. https://doi.org/10.1111/j.1365-2929.2005.02140.x

Holt, L., \& Brockett, R. G. (2012). Self direction and factors influencing technology use: Examining the relationships for the 21st century workplace. Computers in Human Behavior, 28(6), 2075-2082. https://doi.org/10.1016/j.chb.2012.06.011

Hung, M.-L., Chou, C., Chen, C.-H., \& Own, Z.-Y. (2010). Learner readiness for online learning: Scale development and student perceptions. Computers \& Education, 55(3), 1080-1090. https://doi.org/10.1016/j.compedu.2010.05.004

Karakas, F., \& Manisaligil, A. (2012). Reorienting self-directed learning for the creative digital era. European Journal of Training and Development, 36(7), 712-731. https://doi.org/10.1108/03090591211255557

Keller, J. M. (1987). Strategies for stimulating the motivation to learn. Performance + Instruction, $26(8)$, 1-7. http://dx.doi.org/10.1002/pfi.4160260802

Kim, R., Olfman, L., Ryan, T., \& Eryilmaz, E. (2014). Leveraging a personalized system to improve selfdirected learning in online educational environments. Computers \& Education, 70, 150-160. https://doi.org/10.1016/j.compedu.2013.08.006

Kitsantas, A., \& Dabbagh, N. (2011). The role of Web 2.0 technologies in self-regulated learning. New Directions for Teaching and Learning, 2011(126), 99-106. https://doi.org/10.1002/tl.448

Knowles, M. S. (1975). Self-directed learning: A guide for learners and teachers. New York, NY: Association Press.

Lai, H.-J. (2011). The influence of adult learners' self-directed learning readiness and network literacy on online learning effectiveness: A study of civil servants in Taiwan. Educational Technology \& Society, 14(2), 98-106. Retrieved from http://www.ifets.info/download_pdf.php?j_id=51\&a_id=1129

Lee, K., Tsai, P. S., Chai, C. S., \& Koh, J. H. L. (2014). Students’ perceptions of self-directed learning and collaborative learning with and without technology. Journal of Computer Assisted Learning, 30(5), 425437. https://doi.org/10.1111/jcal.12055

Lin, L. (2008). An online learning model to facilitate learners' rights to education. Journal of Asynchronous Learning Networks, 12(1), 127-143. Retrieved from https://onlinelearningconsortium.org/wpcontent/plugins/olc-download/download.php?post_id=4085

Loyens, S. M., Magda, J., \& Rikers, R. J. P. (2008). Self-directed learning in problem-based learning and its relationships with self-regulated learning. Educational Psychology Review, 20(4), 411-427. https://doi.org/10.1007/s10648-008-9082-7

McLoughlin, C., \& Lee, M. J. W. (2010). Personalised and self regulated learning in the Web 2.0 era: International exemplars of innovative pedagogy using social software. Australasian Journal of Educational Technology, 26(1), 28-43. https://doi.org/10.14742/ajet.1100

Merriam, S. B. (2001). Andragogy and self-directed learning: Pillars of adult learning theory. In S. B. Merriam (Ed.), New directions for adult and continuing education (pp. 3-13). San Francisco, CA: JosseyBass. https://doi.org/10.1002/ace.3

Merriam, S. B., \& Bierema, L. L. (2014). Adult learning: Linking theory and practice. San Francisco, CA: Jossey-Bass.

Moos, D. C., \& Azevedo, R. (2009). Learning with computer-based learning environments: A literature review of computer self-efficacy. Review of Educational Research, 79(2), 576-600. https://doi.org/10.3102/0034654308326083

Oddi, L. F. (1986). Development and validation of an instrument to identify self-directed continuing learners. Adult Education Quarterly, 36(2), 97-107. https://doi.org/10.1177/0001848186036002004 
Park, H. (2013). Effect of self-directed learning readiness by learner's interaction on social network games. Journal of Cases on Information Technology, 15(3), 47-60. https://doi.org/10.4018/jcit.2013070104

Raidal, S. L., \& Volet, S. E. (2008). Preclinical students’ predispositions towards social forms of instruction and self-directed learning: a challenge for the development of autonomous and collaborative learners. Higher Education, 57(5), 577-596. https://doi.org/10.1007/s10734-008-9163-z

Rashid, T., \& Asghar, H. M. (2016). Technology use, self-directed learning, student engagement and academic performance: Examining the interrelations. Computers in Human Behavior, 63, 604-612. https://doi.org/10.1016/j.chb.2016.05.084

Robertson, J. (2011). The educational affordances of blogs for self-directed learning. Computers \& Education, 57(2), 1628-1644. https://doi.org/10.1016/j.compedu.2011.03.003

Ryan, J. (2012). Meeting them halfway: Using social networking to connect with students. In S. Kelsey \& K. St.Amant (Eds.), Computer-mediated communication: Issues and approaches in education (pp. 1-14). Hershey, PA: IGI Global. https://doi.org/10.4018/978-1-61350-077-4.ch001

Sadaf, A., Newby, T. J., \& Ertmer, P. A. (2012). Exploring factors that predict preservice teachers' intentions to use Web 2.0 technologies using decomposed theory of planned behavior. Journal of Research on Technology in Education, 45(2), 171-195. https://doi.org/10.1080/15391523.2012.10782602

Şahin, E., \& Erden, M. (2009). Özyönetimli öğrenmeye hazırbulunuşluk ölçeği’nin (ÖYÖHÖ) geçerlik ve güvenirlik çalışması [Reliability and validity of self-directed learning readiness scale (SDLRS)]. $e$-Journal of New World Sciences Academy, 4(3), 695-706. Retrieved from http://dergipark.gov.tr/download/articlefile/185900

Sharma, T. C. (2004). Meaning of lifelong learning. New Delhi: Sarup \& Sons.

Simmering, M. J., Posey, C., \& Piccoli, G. (2009). Computer self-efficacy and motivation to learn in a selfdirected online course. Decision Sciences Journal of Innovative Education, 7(1), 99-121. https://doi.org/10.1111/j.1540-4609.2008.00207.x

Song, D., \& Bonk, C. J. (2016). Motivational factors in self-directed informal learning from online learning resources. Cogent Education, 3(1), 1-11. https://doi.org/10.1080/2331186X.2016.1205838

Song, L., \& Hill, J. R. (2007). A conceptual model for understanding self-directed learning in online environments. Journal of Interactive Online Learning, 6(1), 27-41. Retrieved from http://www.ncolr.org/jiol/issues/pdf/6.1.3.pdf

Söylemez, N. H., \& Oral, B. (2013). Öğretmen adaylarının bilgisayara ilişkin öz-yeterlik algılarının çeşitli değişkenler açısından incelenmesi [Analysis of preservice teachers' computer related self efficacy perception according to various variables]. Bartın Üniversitesi Eğitim Fakültesi Dergisi 2(1), 44-60. Retrieved from http://dergipark.gov.tr/download/article-file/43562

Tabachnick, B. G., \& Fidell, L. S. (2007). Using multivariate statistics. Boston, MA: Pearson/Allyn \& Bacon.

Teo, H.-H., Wan, W., Chan, H., \& Lim, C.-Y. (2002). Bridging the digital divide: The effects of home computer ownership and school IT environment on self-directed learning. Proceedings of International Conference on Information Systems (ICIS) 2002 (pp. 641-650). Retrieved from http://aisel.aisnet.org/icis2002/59

Teo, T., Tan, S. C., Lee, C. B., Chai, C. S., Koh, J. H. L., Chen, W. L., \& Cheah, H. M. (2010). The selfdirected learning with technology scale (SDLTS) for young students: An initial development and validation. Computers \& Education, 55(4), 1764-1771. https://doi.org/10.1016/j.compedu.2010.08.001

Vonderwell, S., \& Turner, S. (2005). Active learning and preservice teachers' experiences in an online course: A case study. Journal of Technology and Teacher Education, 13(1), 65-84. Retrieved from http://learntechlib.org/p/18892/

Wang, D., Xu, L., \& Chan, H. C. (2014). Understanding the continuance use of social network sites: A computer self-efficacy perspective. Behaviour \& Information Technology, 34(2), 204-216. https://doi.org/10.1080/0144929X.2014.952778

Wilcox, S. (1996). Fostering self-directed learning in the university setting. Studies in Higher Education, 21(2), 165-176. https://doi.org/10.1080/03075079612331381338

Wiley, K. (1983). Effects of a self-directed learning project and preference for structure on self-directed learning readiness. Nursing Research, 32(3), 181-185. https://doi.org/10.1097/00006199-198305000$\underline{00011}$ 
Yurdugül, H., \& Sırakaya, D. A. (2013). Çevrimiçi öğrenme hazır bulunuşluluk ölçeği: Geçerlik ve güvenirlik çalışması [The scale of online learning readiness: A study of validity and reliability]. Eğitim ve Bilim, 38(169), 391-406. Retrieved from http://eb.ted.org.tr/index.php/EB/article/view/2420/521

Corresponding author: Evren Sumuer, evren.sumuer@kocaeli.edu.tr

Australasian Journal of Educational Technology @ 2018.

Please cite as: Sumuer, E. (2018). Factors related to college students' self-directed learning with technology. Australasian Journal of Educational Technology, 34(4), 29-43. https://doi.org/10.14742/ajet.3142 